\title{
Human Immunodeficiency Virus Diagnosed from Bilateral Facial Nerve Paralysis as the First Symptom
}

\author{
Soon-Gu Kim ${ }^{1}$, Byung-Woo Yoon ${ }^{2}$ Eui-Kyung Goh', and Se-Joon $\mathrm{Oh}^{2}$ \\ ${ }^{1}$ Department of Otorhinolaryngology-Head and Neck Surgery, Pusan National University School of Medicine and \\ Medical Research Institute, Pusan National University Yangsan Hospital, Yangsan; and \\ ${ }^{2}$ Department of Otorhinolaryngology-Head and Neck Surgery, Pusan National University Hospital, Busan, Korea
}

\section{양측성 안면마비로 처음 확인된 인간면역 결핍 바이러스 감염증}

김순구 ${ }^{1} \cdot$ 윤병우 $^{2} \cdot$ 고의경 $^{2} \cdot$ 오세준 $^{2}$

부산대학교 의학전문대학원 양산부산대학교병원 이비인후과학교실, ${ }^{1}$ 부산대학교병원 이비인후과 ${ }^{2}$

\author{
Received November 2, 2014 \\ Revised January 28, 2015 \\ Accepted February 8, 2015 \\ Address for correspondence \\ Se-Joon Oh, MD \\ Department of Otorhinolaryngology- \\ Head and Neck Surgery, \\ Pusan National University Hospital, \\ 179 Gudeok-ro, Seo-gu, \\ Busan 602-739, Korea \\ Tel +82-51-240-7336 \\ Fax $+82-51-246-8668$ \\ E-mail o3jdoc@hanmail.net
}

The incidence of neurological complication has subsequently increased with the rise of human immunodeficiency virus (HIV) infection. Peripheral facial palsy, one of the presenting symptoms of neurological complications, is caused by HIV infection. Worldwide reported cases of bilateral facial palsy associated with HIV are extremely rare, with just 20 cases reported. In this case, bilateral facial palsy occurred during the first clinical manifestation of the HIV infection. It is important to recognize bilateral facial palsy as the first sign of HIV infection due to its significance for early diagnosis and treatment of HIV.

Korean J Otorhinolaryngol-Head Neck Surg 2015;58(8):576-9

Key Words Facial paralysis · Human immunodeficiency virus.

\section{서 론}

인체 면역결핍 바이러스(human immunodeficiency virus, $\mathrm{HIV}$ ) 감염은 매년 증가 추세에 있으며 그에 따라 기회감염 의 발생도 확대되고 있다. 뿐만 아니라 치료법의 발달로 생존 율이 향상되고 HIV와 관련된 질환도 증가하고 있다. ${ }^{1)} \mathrm{HIV}$ 감염 환자의 $70 \%$ 정도는 유병기간 동안 신경학적인 합병증 을 경험하는 것으로 알려져 있고, 이 중 14 27\%에서 말초 신경병증이 발생하며, 1 4\%는 단일 신경병증을 경험한다. ${ }^{2)}$ 말초성 안면신경마비는 흔히 HIV 감염의 초기 무증상기에 첫 번째 증상으로 나타나며, 일반적으로 예후가 좋은 편이지 만, 진행된 HIV 감염의 후기합병증으로도 발생할 수 있다. ${ }^{2}$

양측성 안면신경마비는 편측 발병 후 30 일 이내 반대 측의 불완전 혹은 완전마비가 발생하는 것으로 정의되며, 안면마 비 환자의 $0.3 \%$ 에서 $2 \%$ 정도만 발병하는 드문 질환이다. ${ }^{2)}$ 일 측성도 마찬가지이지만, 양측성 안면신경마비는 외상, 중추
신경계 이상, 전신적인 질환, 감염, 의인성, 특발성 등 다양한 원인 질환이 있는 경우가 더 많기 때문에 엄격한 평가와 경과 관찰을 하여 원인 질환을 치료하도록 해야 한다. 감별진단으 로는 벨 마비(Bell's palsy), 길랑-바레 증후군(Guillain-Barre syndrome), 매독(syphilis), 신경유육종증(neurosarcoidosis), 라임 병(Lyme disease), 백혈병(leukemia), 세균성 수막염 (bacterial meningitis), 구강안면 육아종증(orofacial granlomatosis) 등이 알려져 있다. ${ }^{3)}$

$\mathrm{HIV}$ 와 관련된 양측성 안면신경마비는 아주 드물어서 전 세 계적으로는 1989년 HIV 양성 환자에서의 양측성 안면신경마 비가 처음 보고된 이후로 20예 정도만이 보고되었고, ${ }^{2}$ 국내 에서는 내과 저널을 통한 1 예가 보고되었다. ${ }^{4)}$ 지금까지 보고 된 양측성 안면신경마비는 대개 순차적으로 발생하는 데 반 해, ${ }^{2}$ 본 증례에서는 동시에 양측성 안면신경마비가 발생하였 고, HIV 진단 전의 급성기에 발생하였다. 따라서 양측 안면신 경마비가 HIV 감염의 첫 증상이 될 수 있으므로 조기 진단 


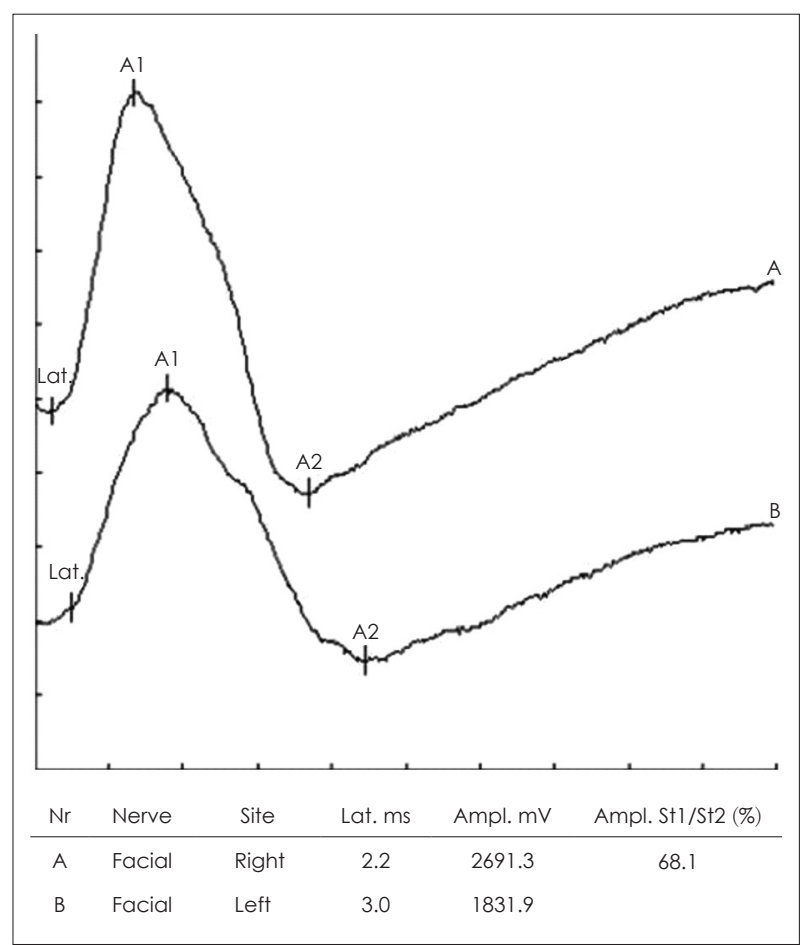

Fig. 1. Electroneuronography on 5th admission day. Left side amplitude $(1831.9 \mathrm{mV})$ is lower by $30 \%$ compared to the right side amplitude (2691.3 mV). Nr: number, Lat.: latency, Ampl.: amplitude.

을 통해 치료를 시작할 수 있다는 것이 임상적으로 중요한 의 미를 지닌다고 생각되며, 문헌 고찰과 함께 보고하고자 한다.

\section{증 례}

29세 남자 환자가 발열, 오한, 두통, 전신위약감, 구토로 근 처 이비인후과를 방문하여 치료를 받았으나 열이 지속되고 호 전이 없었지만 흉부방사선촬영 상 이상 소견 없어 보존적 치 료를 하던 중 증상 발생 12 일째 음식물이 입에서 흐르고 양측 눈이 감기지 않아 안면마비 의심 하에 본원으로 전원되었다. 환자는 과거력 상 수년 전 임질로 치료를 받았으며, 내원 시 양측 이마의 움직임이 없고 눈은 노력 시에도 감기지 않는 등, House-Brackmann classification grade IV의 양측 안면신경 마비가 관찰되었다.

이통은 없었고 양측 고막은 정상 소견이었다. 또한 외이도 나 이개, 안면부의 피부 병변은 관찰되지 않았다. 양측 고막 은 정상이었고 고실도(tympanometry) 상 양측 고막 모두 A 형이 나왔으며 순음청력검사 상 정상 범위였다. 안면마비 이 외의 다른 뇌신경학적 이상 소견은 관찰되지 않았다. 치료를 먼저 시작하기로 하고 항바이러스제인 valcyclovir(Zovirax ${ }^{\circledR}$ Dong-A Pharm, Seoul, Korea)을 $5 \mathrm{mg} / \mathrm{kg}$ 씩 8시간마다 5일간 의 정맥주사와 전신 스테로이드(prednisolone $1 \mathrm{mg} / \mathrm{kg}$ ) 투
여를 7일간 유지하고, 이후 7일에 걸쳐 감량하였다. 안면신경 마비 5일째 신경전도 검사(electroneuronography) 상 우측에 비해 좌측이 $30 \%$ 가량 감소된 소견이었지만, 외관상 우측과 좌측의 마비의 정도는 차이가 나지 않았다(Fig. 1). 측두골 자기공명영상촬영에서는 이상 소견이 관찰되지 않았으며, 치 료와 동시에 여러 혈청학적인 검사를 시행하였는데, cytomegalovirus, varicella-zoster virus, epstein-barr virus, herpes simplex virus, Venereal Disease Research Laboratory test 와 toxoplasmosis에 대해서는 음성반응을 나타내었다. 그람 염색 및 배양검사에서 어떤 균이나 곰팡이류가 동정되지는 않았고 시행한 뇌척수액 천자에서는 무균성 뇌 수막염의 소견 (protein $68 \mathrm{mg} / \mathrm{dL}$, leukocyte count 52 cells/uL, lymphocyte $90 \%$, glucose $57 \mathrm{mg} / \mathrm{dL}$ )이었다. 그리고 HIV 검사에서 효소면역측정법(enzyme-linked immunosorbent assay) 양 성반응이 나와서 웨스턴 블롯(Western blot)으로 확진되었 다. 또한 CD4 T세포는 $278 \mathrm{cells} / \mathrm{mm}^{3}$ (정상 범위, 400 1850 cells $/ \mathrm{mm}^{3}$ ), $\mathrm{CD} 8$ T세포는 정상 범위, $\mathrm{CD} 4 / \mathrm{CD} 8$ 비는 0.1(정상 범위, 1.0 2.0), 정량검사인 HIV viral load는 2850000 copies/ $\mathrm{mL}$ 로 확인되었다. 임질로 치료받은 과거력이 있어 다시 한 번 성전파성 질환(sexually transmitted disease, STD)에 대해 서 평가를 시행하였고 음성으로 나왔다. 즉시 감염내과에 의뢰 를 하여 항레트로바이러스제(atazanavir, ritonavir, tenofovir) 를 투여하기 시작하였다. 안면신경마비 발생 13일째 항레트 로바이러스제를 투여하기 시작하자 증상은 급속히 호전되어 16일째 House-Brackmann grade I으로 완전히 회복이 되었다.

\section{고 찰}

문헌에 보고된 $\mathrm{HIV}$ 감염 환자에서 이비인후과 질환의 유 병률은 41 68\%로 다양하게 보고되고 있는데, 2009년 본원 에서는 $10.5 \%$ 로 외국에 비해서 낮았다. 이는 병원에 등록된 $\mathrm{HIV}$ 감염 환자 모두에서 이비인후과 질환을 검사한 것이 아 니고 이비인후과 외래를 내원한 환자를 대상으로 하였기 때 문이라고 생각된다.) 당시 연구에서 HIV 감염과 관련된 이비 인후과 질환으로는 급, 만성 중이염 및 만성 부비동염이 가장 많이 관찰되었고, 일측성 안면신경마비는 $2.5 \%$ 인 1 예에서만 관찰되었다. 그 후 양측성 안면신경마비 증례를 경험하였다.

$\mathrm{HIV}$ 감염과 관련된 양측성 안면신경마비는 전 세계적으로 는 20예 정도만이 보고되었다. 20예 중 15 명이 남자 환자였고 5 명이 여자 환자였으며, 대부분의 경우 성적 접촉을 통하여 HIV에 감염되었고, 20예 모두 진단 당시 증상이 없는 보균자 였다. 치료는 14 예에서는 대증적인 치료를 하였고 2예에서는 HIV에 대한 항바이러스 치료를, 4 예에서는 치료에 대한 자료 
를 찾을 수 없었다. 본 증례처럼 첫 증상으로 안면신경마비가 발병한 경우는 1예에 불과했고, 대부분 무균성 수막염(aseptic meningitis)이 가장 흔하였다. 경과 관찰 동안 2예를 제외 한 18예에서 수 주 안에 안면신경마비 증상의 뚜렷한 호전을 보였다. ${ }^{2)}$

HIV 감염과 관련된 말초성 안면신경마비는 대부분 특발 성이므로 여러 문헌에서 안면신경마비가 HIV로 인한 것으로 진단하는데 필요한 기준은 따로 존재하지는 않았으며, 다만 모든 증례에서 HIV에 이환된 기간 중에 양측성 안면신경 마 비가 발현된 경우를 대상으로 하였다. 그렇기 때문에 본 증례 뿐만 아니라 기존의 다른 증례에서도 HIV와 관련이 많은 STD가 안면신경마비에 관련되었을 가능성은 존재한다고 할 수 있다. 하지만 본 증례에서는 HIV 감염 외에는 다른 모든 검사에서는 특이 소견을 보이지 않았다.

HIV는 CD4 T세포를 공격하는 레트로바이러스(retrovirus)로서, 급성 HIV 감염(acute HIV infection)은 대개 HIV-1 노 출 후 2 4주 정도에 나타난다.) $\mathrm{HIV}$ 에 감염된 환자의 40 90\% 는 발열, 위약감, 두통, 발진, 림프절 병을 호소하는 급성 HIV 감염을 겪고 바이러스 노출 후 4 10주 정도에 혈청전환(seroconversion)이 일어난다. ${ }^{6}$

안면신경마비는 HIV와 관련된 뇌신경 질환 중 가장 흔한 것으로 알려져 있으며 HIV 감염 초기에서 후기까지 모든 병 기에서 발생할 수 있다.) 여러 문헌에서 말초성 안면신경마비 는 HIV 감염의 어느 단계에서도 발생할 수 있지만 이런 급성 HIV 감염에서 무균성 뇌수막염을 비롯해서 안면신경마비가 더 잘 발생할 수 있다. ${ }^{8)}$ 하지만 HIV를 조기에 진단하는 것은 쉽지 않으며 급성 HIV 감염과 관련된 말초성 안면신경마비 가 혈청전환보다 4 6주 정도 선행하기 때문에 간과되기 쉽 다. 따라서 이전의 검사에서 음성이 나왔더라도 HIV가 풍토 적인(endemic) 지역이거나 문진 상 감염의 위험이 높다면 몇 주 후 반복적인 HIV 검사를 하는 것이 중요하다. ${ }^{2)} \mathrm{HIV}$ 감염 환자에서 벨 마비의 발생은 일반 인구(0.04\%)에 비해 높은 것 으로 보인다. ${ }^{9}$ Schielke 등 ${ }^{10)}$ 은 HIV 감염 환자의 $4.1 \%$ 에서 안 면신경마비가 발생하였다고 보고하였고, Lalwani와 Sooy ${ }^{11)}$ 는 $6.2 \%$ 라고 보고하였다. 하지만 실제로는 단순포진(herpes simplex), 대상포진(herpes zoster) 등이 HIV 감염에서 이미 존재하는 경우가 많기 때문에 HIV 감염 환자에서 안면신경마 비의 유병률이 상대적으로 높게 보인다고 생각할 수 있다. 한편 안면신경마비에서 HIV 감염의 양성 예측치(predictive value) 는 $64 \%$ 에서 $100 \%$ 까지 보고된 바 있으며, 이는 서로 다른 변이 종의 HIV에 감염되었거나, 심지어 같은 종의 HIV라도 바이 러스의 안면신경에 대한 친화성에 대한 차이에 의한 것으로 생각된다. ${ }^{12-14)}$
HIV 감염에서의 말초성 안면신경마비에는 여러 가지 요인 이 관여할 것이라고 추정되는데, 특히 HIV 감염 초기와 후 기에서의 마비로 나뉘며 병기에 따라 병태 생리가 다른 것으 로 알려져 있다. HIV 감염 초기에는 벨 마비처럼 HIV가 안 면신경으로 직접적인 침범을 하는 것이 안면신경에서 검출됨 으로써 증명되었고 ${ }^{15)}$ 또 다른 경우는 면역학적으로 매개된 안 면신경의 탈수초화로 발생하는 경우로서 길랑-바레 증후군 과 유사하다. 그리고 HIV 감염 후기에는 세포면역이 감소함 에 따라 기회감염에 대항하는 방어 체계가 약해짐으로써 대 상포진과 연관된 안면신경마비나 뇌막성 림프종증에 2차성 으로 안면신경 침범, 다양한 만성 안면 신경병증의 발현 등으 로 발생할 수 있다."

$\mathrm{HIV}$ 감염과 관련된 안면신경마비에서 타 장기 침범을 확 인하기 위해 필요한 검사로는 gadolinium 증강 측두골 자기 공명영상인데 중추신경계 병변의 확인을 위해 유용하며, 특 히 양측 안면신경마비에서는 더욱 그 필요성이 높아진다. ${ }^{11}$ $\mathrm{HIV}$ 는 일반적으로 신경을 잘 침범하며 그럴 경우 신경 내 부 종과 섬유 팽창을 유발하고 자기공명영상촬영에서 침범된 안 면신경의 신호 증강이 나타난다. 그러나 이번 증례에서는 측 두골 자기공명영상촬영에서 정상 소견을 나타내었다.

$\mathrm{HIV}$ 감염에서의 안면신경마비의 치료는 벨 마비와 유사 하며, 일반적으로 항바이러스제를 사용하면 된다. 스테로이 드 사용은 아직 논란의 여지가 많지만 면역기능이 충분한 환 자에서는 사용할 수 있다. 하지만 본 증례처럼 양측을 침범한 다면 스테로이드는 각막 노출, 토안(lagophthalmos), 유루증 (epiphora) 등의 안과적 합병증의 가능성을 막기 위해 짧은 기 간이라도 투여해야 한다. ${ }^{9}$ 항HIV 약제를 투여해 보는 것에 대 해서는 아직 보고된 연구는 없었으나, 본 증례에서는 HIV에 대한 치료를 하면서 안면마비는 급속히 호전되었다. HIV 감 염에서의 안면신경마비에 항HIV 약제의 효과가 기존의 스테 로이드 치료보다 더 효과적인지에 대한 연구는 아직 없었으 며, 본 증례에서도 안면신경마비의 급속한 호전이 항HIV 약 제의 효과인지는 확인할 수 없다.

HIV 감염에서 발생한 안면신경마비의 예후는 HIV 감염의 어떤 단계에서 나타났느냐에 따라 달라지지만 대부분은 전형 적인 벨 마비의 단계를 따른다. 완전 회복에는 15 일에서 6 개월 정도 소요되며, 본 증례에서도 16 일이 소요되었다. 특히 기존 치료 방법인 스테로이드 및 항바이러스제를 사용할 때보다 HIV 양성을 확인하고 항레트로바이스제를 투여하면서 급격 히 마비가 호전되었는데, 이는 신경을 침범한 HIV가 감소하 면서 호전되었다고 생각된다. 편측 안면마비보다 양측 안면 마비가 더욱더 심각한 질환이지만, 회복에 있어서는 동시에 회복이 되지는 않더라도 불완전 회복보다는 완전한 회복이 
더 많이 보고되고 있다. ${ }^{8)}$

HIV에 대한 치료 결과는 갈수록 향상되고 있어 최근에는 만성질환으로 여겨지고 있는 것이 사실이나, 늦게 진단될 경우 의학적, 법적으로 문제가 될 수 있다. 따라서 양측성 안면마비 환자에서 HIV 감염을 항상 염두에 두는 것이 HIV 감염의 조 기 진단과 치료를 위해 중요할 것으로 생각된다.

\section{Acknowledgments}

This work was supported by clinical research grant from Pusan National University Hospital 2015.

\section{REFERENCES}

1) Cho KS, Lee DG, Park YD, Shin SC, Lee SH, Roh HJ. Analysis of Otorhinolaryngologic disease in patients with human immunodeficiency virus infection. Korean J Otorhinolaryngol-Head Neck Surg 2009;52 (6):506-11.

2) Abboud O, Saliba I. Isolated bilateral facial paralysis revealing AIDS: a unique presentation. Laryngoscope 2008;118(4):580-4.

3) Rowlands S, Hooper R, Hughes R, Burney P. The epidemiology and treatment of Bell's palsy in the UK. Eur J Neurol 2002;9(1):63-7.

4) Kim MS, Yoon HJ, Kim HJ, Nam JS, Choi SH, Kim JM, et al. Bilateral peripheral facial palsy in a patient with Human Immunodeficiency Virus (HIV) infection. Yonsei Med J 2006;47(5):745-7.

5) Ruiz LM, Kirmani B. Presentation of Bilateral Peripheral Seventh Cranial Nerve Palsy in an HIV Patient. Case Rep Neurol Med 2012; 2012:267405.

6) Kassutto S, Rosenberg ES. Primary HIV type 1 infection. Clin Infect Dis 2004;38(10):1447-53
7) Alcaraz García SF, Muñoz Málaga A, Anglada Pintado JC, Girón Ubeda JM. [Isaolated facial diplegia associated with acute HIV infection]. Rev Clin Esp 2003;203(4):217.

8) Serrano P, Hernández N, Arroyo JA, de Llobet JM, Domingo P. Bilateral Bell palsy and acute HIV type 1 infection: report of 2 cases and review. Clin Infect Dis 2007;44(6):e57-61.

9) Pletcher SD, Goldberg AN. Head and Neck Manifestations of Human Immunodeficiency Virus Infection. In: Cummings CW, Haughey BH, Thomas JR, editors. Cummings Otolaryngology-Head and Neck Surgery. 4th ed. Philadelphia: Mosby;2005. p.316-50.

10) Schielke E, Pfister HW, Einhäupl KM. Peripheral facial nerve palsy associated with HIV infection. Lancet 1989;1(8637):553-4.

11) Lalwani AL, Sooy CD. Otologic and neurologic manifestations of acquired immunodeficiency syndrome. Otolaryngol Clin North Am 1992;25:1183-97.

12) Di Costanzo B, Belec L, Testa J, Georges AJ, Martin PM. [Seroprevalence of HIV infection in a population of neurological patients in the Central African Republic]. Bull Soc Pathol Exot 1990; 83(4):425-36.

13) Kabore J, Debouverie M, Galin M, Sanou S, Verdier M, Denis M, et al. Paralysis faciales idiopathiques et sérologie VIH. Une étude au Burkina. Faso. In: Dumas M, Giordano C, Gentilini M, Chieze F, editors. Neurologie tropicale. Paris: John Libbey Eurotext;1994. p.149-52.

14) Poser CM. Les infection rétro virales sous les tropiques. In: Dumas M, Giordano C, Gentilini M, Chieze F, editors. Neurologie tropicale. Paris: John Libbey Eurotext;1994. p.81-90.

15) Kohler A, Burkhard P, Magistris MR, Chofflon M. [Isolated peripheral facial paralysis and HIV infection: 7 cases]. Rev Neurol (Paris) 1995; 151(5):332-7. 